\title{
ВЛИЯНИЕ 2,3-ДИЗАМЕЩЕННЫХ ХИНОКСАЛИНОВ НА ЦИТОТОКСИЧНОСТЬ В МТТ-ТЕСТЕ
}

\author{
Я.А. Иванова', К.А. Нечаева', К.Т. Султанова ${ }^{1,2}$ \\ ${ }^{1}$ ФГБОУ ВО «Волгоградский государственный медицинский университет» МЗ РФ \\ 400131, Россия, г. Волгоград, площадь Павших Борцов, д. 1. \\ 2ГБУ Волгоградский медицинский научный центр, \\ 400131, Россия, г. Волгоград, площадь Павших Борцов, д. 1.
}

DOI: 10.19163/MedChemRussia2021-2021-339

E-mail:yanabaileys@gmail.com

Производные 2,3-дизамещенных хиноксалинов представляют собой биологически активные вещества с разнообразными фармакологическими эффектами, в связи с чем они потенциально перспективны для углубленного изучения их активности [1]. Поэтому целесообразным является провести первичную оценку их цитотоксического профиля для определения возможности их использования в дальнейших исследованиях.

Целью работы стала оценка влияния новых 2,3-дизамещенных хиноксалинов на метаболическую активность культуры клеток гепатомы человека HepG2 в МТТ-тесте. Исследуемые вещества синтезированы сотрудниками НИИ «ФОХ» ЮФУ Л.Н. Диваевой и А.А. Зубенко. Общая структурная формула изученных веществ представлена на рисунке:

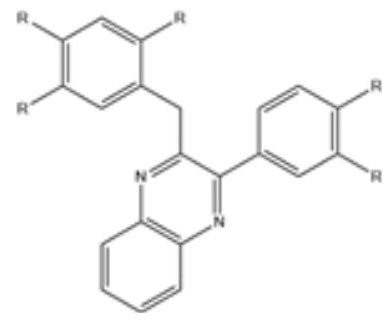

Цитотоксичность изучалась в стандартном колориметрическом МТТ-тесте [2]. Обработка данных проводилась в ПО GraphPad Prism v.8.0 методом нелинейной регрессии. Соединения под шифрами $\mathrm{I}_{B}, \mathrm{I}_{C}, \mathrm{I}_{\mathrm{D}}$ снижали выживаемость клеток в концентрациях 1,9 мкМ, 0,19 мкМ и 1,5 мкМ соответственно. Для соединения I в максимальной исследуемой концентрации изменение метаболической активности клеток не превысило 50\%. Таким образом, наименьший уровень цитотоксичности показало соединение I, что делает его наиболее безопасным и перспективным для дальнейшего изучения.

Авторы выражают благодарность Л.Н. Диваевой и А.А. Зубенко за синтез целевых веществ.

\section{Литература}

[1] D. V. Maltsev, A. A. Spasov, D. S. Yakovlev, et al., Eur. J. Pharmaceutical Sciences. 2021. Vol. 161, P. 105792.

[2] J.C. Stockert, Acta Histochemica. 2018, Vol. 120(3), P. 159-167. 